\title{
The Level of Satisfaction of Female Learning Disabilities' Parents with Their Kids' Integration in Regular Schools in Riyadh, Saudi Arabia
}

\author{
Wedad A. Abahusain ${ }^{1}$ \\ ${ }^{1}$ Special Education Department, College of Education, King Saud University, Saudi Arabia \\ Correspondence: Wedad A. Abahusain, Special Education Department, College of Education, King Saud \\ University, Prince Turkey street, Exit 2, Riyadh, Saudi Arabia. Tel: 966-558-052-555. E-mail: \\ prof.wedad.a@gmail.com
}

Received: November 3, 2015 Accepted: December 21, 2015 Online Published: May 29, 2016

doi:10.5539/ies.v9n6p196

URL: http://dx.doi.org/10.5539/ies.v9n6p196

\begin{abstract}
This study aims at finding out the parents' level of satisfaction with the integration of their daughters with learning disabilities in regular schools in Riyadh, Saudi Arabia. The study sample consisted of 283 parents of female students. The instrument of data collection was a questionnaire consisting of 59 items for 10 domains. The study results indicated that the services provided by the resources rooms in regular schools gained the highest parents' satisfaction, followed by the services related to the means and methods used by the resources room's teacher. However, the extracurricular services gained the lowest level of parents' satisfaction. In light of the results of the current study, a number of pedagogical implications can be presented to decision makers to improve the resources room which leads to an increase of the satisfaction level of female learning disabilities' parents with their kids' integration in regular schools in Riyadh, Saudi Arabia.
\end{abstract}

Keywords: satisfaction, learning, disabilities, services, resources, rooms, Riyadh

\section{Introduction and Background}

Children with Learning Disabilities (LD) need to receive Special Education Services as their counterparts in other categories due to the difficulties facing them in learning various academic skills within the regular classroom. These difficulties often render the students unable to benefit from the activities and experiences provided in the classroom, in spite of possessing appropriate mental abilities which qualify them to continue and benefit from their education in various aspects of life (Awwad \& Al-Imam, 2007).

Learning disabilities have received a considerable attention in literature due to the diversity of their manifestations, the extent of their spread, and the diversity of the educational programs which aim at treating them. Smith (2004) points out that the American Federal Government in 1999 provided a definition for learning disabilities, "Special Learning Disability", which means a disorder in one or more of the psychological processes used in understanding or using spoken or written language, and which is manifested in the incomplete ability to listen, think, speak, read, write, and spell. Learning disabilities also include cases or conditions, such as cognitive disabilities, brain injury, minimal brain dysfunction, dyslexia, and verbal developmental dyspraxia. The definition does not include the learning difficulties resulting from visual, motor, auditory, or mental disabilities, emotional disorders, or economic, environmental, and cultural deprivation.

The World Health Organization's report, entitled "Child Trends of the National Health Interview Surveys, 2006", indicates that the percentage of children whose age ranged between 3 to 17 identified to have learning disabilities between 1997 and 2004 ranged from 7\% to 8\%; 10\% males and 6\% female. Jaffe and Segal (2005) mention that almost one out of every seven people in the United States suffers from learning disabilities. In Arabic studies, the percentage of learning disabilities in the elementary schools ranged between $22.7 \%$ and $50 \%$ (Al-Hadidi, 2003). This ensures the provision of educational services for people with special needs, including those with learning disabilities in less restrictive settings (Crockett \& Kauffman, 1999).

The resources room is considered as one of the educational alternatives in which students with learning disabilities receive services which help them overcome the academic and developmental problems they suffer from (Frend \& Bursuck, 2002). A few people also consider learning disabilities and the resources room two sides of the same coin since the children with learning disabilities are the most frequent users of the resources room 
(Al-Sartawi \& Abunyan, 1998). However, the resources room's programs require a development in line with the characteristics of those students as well as with the supporters of this model in order to be continuously viewed as an important alternative in special education (McNamer, 1998). It is also known that the learning disabilities category is one of the most prevalent and integrated categories among people with special needs (Lerner, 2000).

Over twenty years, studies have shown that the education of children with special needs can be more effective by enhancing the parents' role and ensuring the availability of real opportunities for the families of those children to participate in their children's education at school and at home. Laws in the United States also have ensured the protection of the rights of students with disabilities and their parents since first issuance of these laws (93-380) in 1974 to the last laws issued in 2004. The law (IDEA, 2004) referred to making the parents main partners in the educational institutions for making all decisions related to their children (Abunyan, 2012). Laws were further followed by other bylaws that enabled the families to actively contribute with the official institutions to make decisions related the education and rehabilitation of their children. This enabled the families to become awarded partners in the decision making (Abunyan, 2007; Awwad \& Imam, 2007).

Al-Khatib and Al-Hadidi (2003) highlighted the importance of the role of special education teachers in encouraging cooperation with their colleagues, teachers of general education in school, in addition to their prominent role with parents. Studies have shown that the participation of parents with their children in the educational programs and activities inside and outside schools, institutions, and centers is necessary for making relevant decisions. Gallagher (1995) also confirmed that the parents' understanding of the special education program, the clarity of the program's objectives and its instructions, and the participation of the parents in the educational activities aids significantly improved the relationship between the teacher and the parents. This makes them aware of the academic progress of their children.

Based on the aforementioned, this study aims at evaluating the extent of satisfaction of the parents of female students with learning disabilities with the services offered to their daughters in the resources rooms in regular schools of Riyadh, Saudi Arabia.

\subsection{Significance of the Study}

The current study aims at shedding light on an important and a complementary topic of the integration process, which is the satisfaction of the parents with the integration of their daughters with learning disabilities in regular schools. Thus, the current study offers real data about the degree of the parents' satisfaction with the integration of their daughters with learning disabilities in regular schools, and provides the concerned parties with data on the status of integrating female students with learning disabilities.

\subsection{Statement of the Problem}

Although there are many studies on integration, only few studies have been published on integrating female students with learning difficulties in regular schools in Saudi Arabia. Thus, this study aims to highlight an important and complementary subject of the integration process, which is the parents' satisfaction with the integration of their daughters with learning disabilities in regular schools. More specifically, this study attempted to answer the following question:

What is the level of the parents' satisfaction with the services offered by the resources rooms to their daughters with learning disabilities?

\subsection{Terms of the Study}

Female Students with Learning Disabilities: are those who appear to have a disorder in one or more of the basic psychological processes, which include understanding the written and spoken language and its use. Disorders also appear in the hearing, thinking, speaking, reading, spelling and arithmetic disorders which are due to minimal functional brain injury and have no relationship with any disability, whether mental, audio, visual or any other disability (Al-Rousan, 2001; Al-Mousa, 1999).

The Resources Room: It is a room of special services in school specialized in providing educational services for people with special needs. Students with special needs enrolled in the resources room receive classes in aspects they show problems in according to a specific schedule, and receive other classes in the regular classroom (Lerner, 2000).

Parents' Satisfaction: It is the psychological state of the parents, and it is characterized by conviction and the feeling of relief to achieve their desires and their personal and psychological needs (Lerner, 2000).

\section{Literature Review}

This study is one of the few Arabic studies that addressed the issue of parents' satisfaction with the integration of 
their children with learning disabilities. Some findings varied; some were positive, some were negative, and some others recorded an average level of satisfaction. Below the researcher offers a presentation of Arabic and foreign studies that dealt with the parents' satisfaction with the integration of students with learning disabilities in regular schools.

Some studies showed positive attitudes towards the services provided to students. One of those studies was that carried out by Latter (1986), which aimed to determine the satisfaction of parents with the services provided by the Department of Special Education at the Toronto College. 208 of the parents of students with learning disabilities were interviewed. Parents expressed their relief and satisfaction regarding the services presented to their children. They also mentioned a few problems, such as lack of some material and the long duration of the process.

Another study conducted by Bairat (2005) aimed to determine the satisfaction of the parents of the students with learning disabilities integrated in regular schools. The results indicated a high level of satisfaction with the services offered. The study also revealed that mothers had a higher degree of satisfaction than fathers.

On the other hand, some studies reflected negative attitudes towards the services provided to students in resources rooms. For example, Stephenson (1992) aimed to find out the extent of parents' satisfaction with the integration of their children in the resources rooms. The researcher interviewed four mothers of children with learning disabilities enrolled in the resources rooms, aged (10-18 years). A year after the enrollment of these students in the resources rooms, the mothers showed high levels of frustration and dissatisfaction and lack of satisfaction with the integration of the children, and their enrollment in the resources rooms or the services provided.

Spann and Soenksen (2003) also conducted a study that focused on identifying the level of the parents' satisfaction with the services provided to their children in schools. The sample of the study consisted of 45 parents. The results showed parents' dissatisfaction with the level of services and programs and that the school does not offer much to meet their needs.

Ayed's (2003) study aimed to reveal the problems facing resources room's teachers in Jordan. The results indicated that one of these problems related to the parents of the students was their expectation to achieve rapid results with their children in the resources room. Other problems included parents' thoughts about their children's problems and their lack of effective cooperation with the school.

Finally, upon reviewing previous studies, the researcher finds that the results of the previous studies varied. Most of the results showed that some parents are satisfied, while some showed negative attitudes toward the integration process. A few other studies gained an average level of satisfaction. This increases the importance of carrying out the current study in order to tip the satisfactory level, whether it is positive or negative, in order to determine the reasons behind these attitudes. The current study focuses on the level of satisfaction of female students with learning disabilities' parents with the services provided to their daughters. To the best of the researcher's knowledge, this study is considered one of its kind in the Kingdom of Saudi Arabia, as it addresses the parents' satisfaction with the services provided in the resources rooms.

\section{Methodology}

\subsection{Method}

The researcher used an analytical descriptive method in this study, which is defined by Assaf as "A research done by questioning all members of the research community or a large sample of them in order to describe the studied phenomenon's nature, and working to arrive at the reasons behind this phenomenon." (Al-Assaf, 2006)

\subsection{Instruments}

To achieve the objectives of this research, the researcher used Al-Ayed's questionnaire for data collection (Al-Ayed, 2011) due to its suitability for the objectives of the study. It consisted a set of questions sent by mail to the participating subjects to record their answers, and resend them to the researcher. The subjects did not receive any help from the researcher in understanding the questions or recording their answers.

\subsection{Statistical Analysis}

In order to achieve the objectives of the study and analyze the data collected, several appropriate statistical methods have been employed using the Statistical Package for Social Sciences (SPSS).

In order to determine the length of the cells of 4-point scale (lower and upper limits) used in the domains of the present study, the range was calculated as $(4-1=3)$ and then divided by the number of scale cells to get the correct cell length (i.e. $3 / 4=0.75$ ). This value is added to the lowest value in the scale (or the beginning of the 
scale, which is the whole number) in order to determine the upper limit of this cell, and thus the length of the cells becomes as follows:

- 1 to 1.75 represents (Strongly Disagree) to every statement, without any reference to the domain intended to be measured.

- From 1.76 to 2.50 represents (I do not agree) to every statement, without any reference to the domain intended to be measured.

- From 2.51 to 3.25 represents (agree to every statement, without any reference to the domain intended to be measured.

- From 3.26 to 4.00 is (strongly agree to every statement, without any reference to the domain intended to be measured.

After that, the following statistical values were calculated:

1) Frequencies and percentages to identify the personal and functional characteristics of the members of the study sample, and identify its members' attitudes towards each statement in the domains in the instrument of the present research.

2) "Weighted Mean" in order to identify how high or low the participants' responses of the study to each statement. Note that it is of benefit to arrange the statements according to the highest weighted arithmetic mean.

3) "Mean Scores" in order to identify how high or low the participants' responses are from the domains of the study (Average of mean scores of the statements). Note that it is of benefit to arrange the domains according to the highest mean score.

4) Using Standard Deviation to identify the extent of deviation of the participants' responses to each statement, and each domain from its mean. It is noted that the standard deviation demonstrates the dispersion in the responses of the sample towards each statement and the domains in the study variables. When the standard deviation is close to zero, the responses will be more focused, and the dispersion will be lower on the scale.

5) T-test for Independent Samples was used to identify whether there are statistically significant differences between the attitudes of the participants of the present study towards the domains in the study, irrespective of their variables, which are divided into two categories.

6) One-Way Analysis of Variance (ANOVA) was used to identify whether there were statistically significant differences between the attitudes of the participants towards the domains of the study, irrespective of differences in their personal and functional variables, which are divided into two categories.

7) Scheffé test was used to verify the validity of the differences, which were revealed in the one-way analysis of variance (ANOVA).

\subsection{Analysis of the Study Results}

Description of the Study Sample: Table 1 shows the distribution of the study sample according to the grade variable:

Table 1. Distribution of the Study Sample According to "the Grade" Variable

\begin{tabular}{lcc}
\hline Grade & Frequency & Percentage \\
\hline First Grade & 17 & $6.0 \%$ \\
Second Grade & 59 & $20.8 \%$ \\
Third Grade & 70 & $24.7 \%$ \\
Fourth Grade & 49 & $17.3 \%$ \\
Fifth Grade & 57 & $20.1 \%$ \\
Sixth Grade & 31 & $11.0 \%$ \\
Total & 283 & $100 \%$ \\
\hline
\end{tabular}

As shown in Table 1 above, 70 participants, representing $24.7 \%$ of the total number of participants in the study are in grade 3, which is the largest category in the sample of the study. While 59 participants, representing $20.8 \%$ 
of the total number of the participants in the study is in grade 2, 57 participants, representing $20.1 \%$ were in grade 9 . As noticed, forty nine participants, representing $17.3 \%$ were in grade 4,31 participants, representing a percentage of $11.0 \%$ were in grade 6 , and 17 participants, representing a percentage of $6.0 \%$, were in grade 1 .

Table 2. The distribution of the study sample according to "the Nature of the Relationship to the Child" variable

\begin{tabular}{lcc}
\hline Nature of Relationship & Frequency & Percentage \\
\hline Father & 60 & $21.2 \%$ \\
Mother & 174 & $61.5 \%$ \\
Other & 49 & $17.3 \%$ \\
Total & 283 & $100 \%$ \\
\hline
\end{tabular}

As shown in Table 2, 174 participants of the study sample, representing a percentage of $61.5 \%$ of the total number of participating subjects were mothers. 60 participants, representing $21.2 \%$ were fathers, and 49 participants, representing $17.3 \%$ belonged to "other", which means neither father nor mother.

Table 3. Distribution of the study sample according to "the Educational Level of the Guardian" variable

\begin{tabular}{lcc}
\hline Educational Level of the Guardian & Frequency & Percentage \\
\hline Elementary and Below & 24 & $8.5 \%$ \\
Intermediate & 42 & $14.8 \%$ \\
High School & 76 & $26.9 \%$ \\
Diploma & 31 & $11.0 \%$ \\
Bachelors & 89 & $31.4 \%$ \\
Graduate Studies & 21 & $7.4 \%$ \\
Total & 283 & $100 \%$ \\
\hline
\end{tabular}

As shown in Table 3, 89 parents, representing $31.4 \%$ of the total number of the sample, were Bachelor degree's holders, which is the largest category. 76 parents, representing $26.9 \%$, were high school graduates. Also, 42 of the parents, representing $14.8 \%$ were of intermediate schooling level. 31 parents, representing $11.0 \%$, were holding a Diploma, while 24 of the parents, representing $8.5 \%$, were elementary schooling level or less. However, 21 of the parents, representing $7.4 \%$, were holding post graduate degrees.

Table 4. Distribution of the study sample according to "the Nature of the Family" variable

\begin{tabular}{lcc}
\hline Nature of the Family & Frequency & Percentage \\
\hline A family with a normal child & 98 & $34.6 \%$ \\
A family with participants with learning disabilities & 185 & $65.4 \%$ \\
Total & 283 & $100 \%$ \\
\hline
\end{tabular}

In Table 4, 185 participants, representing $65.4 \%$ of the total study sample, were of families having children with learning disabilities, this is considered the largest category in the study. While 98 participants, representing $34.6 \%$ were of families with normal children. 
Table 5. Distribution of the study sample according to "the Number of Participants who suffer from Learning Difficulties or Disabilities within the Family" variable

\begin{tabular}{lcc}
\hline Number of Participants & Frequency & Percentage \\
\hline One & 180 & $63.6 \%$ \\
Two & 45 & $15.9 \%$ \\
Three & 30 & $10.6 \%$ \\
Four or more & 28 & $9.9 \%$ \\
Total & 283 & $100 \%$ \\
\hline
\end{tabular}

As shown in Table 5, 180 participants of the study sample, representing $63.6 \%$ of the total number of study subjects, had one family member suffering from a learning disability, and this is considered the largest category in the study. While 45 participants, representing $15.9 \%$, had two family members suffering from learning disabilities, 30 participants, representing $10.6 \%$, had three family members suffering from learning disabilities, and 28 participants, representing $9.9 \%$, had four or more family members with learning disabilities.

Table 6. Distribution of the study sample according to "the Time Period in which the Child stayed in the Resources Room"

\begin{tabular}{lcc}
\hline Time Period & Frequency & Percentage \\
\hline One- Two years & 182 & $64.3 \%$ \\
Three years & 76 & $26.9 \%$ \\
Beyond three years & 25 & $8.8 \%$ \\
Total & 283 & $100 \%$ \\
\hline
\end{tabular}

It is shown in Table 6, 182 participants of the study sample, representing 64.3\% stayed from one to two years in the resources room. This represents the largest category. While 76 participants, representing, $26.9 \%$ stayed a total period of three years. 25 participants, representing $8.8 \%$ of the total study sample, stayed more than three years in the resources room.

\section{Results and Discussion}

Mean scores of each item in the questionnaire were found, according to the answer scale and the standard deviation. The mean scores obtained by the sample of the study were also found according to the answer scale for each dimension of the tool and the tool as a whole, in addition to the standard deviation as shown in Table 7. 
Table 7. Mean scores and standard deviations on each domain

\begin{tabular}{lcc}
\hline Domains & Mean & Standard Deviations \\
\hline Intervention and Referral Services & 2.92 & 0.67 \\
Evaluation and Diagnosis Services & 2.82 & 0.67 \\
Class Environment Services & 2.94 & 0.67 \\
Preparation of Individual Educational Plan Services & 2.83 & 0.65 \\
Services provided by the Resources Room teacher & 3.11 & 0.66 \\
Follow-up Services with the parents & 2.80 & 0.67 \\
Extra-Curricular Services & 2.55 & 0.76 \\
Training Services & 2.68 & 0.81 \\
Behavioral Therapy Services & 2.95 & 0.73 \\
Services related to the means and methods Used & 3.08 & 0.73 \\
Tool as a Whole & 2.86 & \\
\hline
\end{tabular}

As shown in Table 7 and by comparing the mean scores of the various domains according to the 4-point scale, the services with the highest percentage of the parents' satisfaction were services provided by the teacher of the resources room with a mean of 3.11. Following in order were the services related to the means and methods used with a mean of 3.08. On the other hand, the services receiving the least parents' satisfaction were the extracurricular services. In general, it was noted that there was an average level of satisfaction according to the scale, where the mean of the tool as a whole reached 2.86.

It is also noticed that the mean scores ranged between 3.16 and 2.37 (See Table 12). Item 31 recorded the highest mean score (3.16) on the domain of the services provided in the resources room-"I see that my child's education by the teacher of the resources room increased his motivation. Item 28-within the domain of services provided by the teacher of the resources room-"the resources room teacher is tactful in dealing with the families". While the lowest mean (2.37) was for item 42 on the domain of extracurricular services-"'The resources room teacher plans scientific trips."

\section{1-Intervention and Referral Services:}

To find out the parents' satisfaction with the intervention and referral services provided by the resources rooms for their children with learning disabilities, frequencies, percentages, mean scores, standard deviations, and ranks of the participants' responses to statements of the domain of intervention and referral services were calculated. The results are shown in Table 8 below: 
Table 8. Responses of the participants to the statements of the domain of intervention and referral services arranged in descending order according to agreement means

\begin{tabular}{|c|c|c|c|c|c|c|c|c|c|}
\hline \multirow{2}{*}{$\begin{array}{l}\text { Statement } \\
\text { No. }\end{array}$} & \multirow[b]{2}{*}{ Statement } & \multicolumn{5}{|c|}{ Degree of Agreement } & \multirow[b]{2}{*}{$\begin{array}{l}\text { Mean } \\
\text { Score }\end{array}$} & \multirow{2}{*}{$\begin{array}{c}\text { Standard } \\
\text { Deviation }\end{array}$} & \multirow[b]{2}{*}{ Rank } \\
\hline & & Percentage \% & $\begin{array}{l}\text { Strongly } \\
\text { Agree }\end{array}$ & Agree & Disagree & $\begin{array}{l}\text { Strongly } \\
\text { Disagree }\end{array}$ & & & \\
\hline 1 & $\begin{array}{l}\text { I believe the } \\
\text { procedures before } \\
\text { referral of my } \\
\text { daughter to the } \\
\text { resources room } \\
\text { were appropriate }\end{array}$ & Fre. & 24.7 & 56.2 & 14.8 & 4.2 & 3.01 & 0.753 & 1 \\
\hline 3 & $\begin{array}{l}\text { I believe the } \\
\text { procedures before } \\
\text { referral of my } \\
\text { daughter to the } \\
\text { resources room } \\
\text { were in the } \\
\text { appropriate time }\end{array}$ & Fre. & 25.1 & 49.8 & 18.7 & 6.4 & 2.94 & 0.831 & 2 \\
\hline 5 & $\begin{array}{l}\text { Appropriate tests } \\
\text { were used to } \\
\text { reveal my } \\
\text { daughter's case }\end{array}$ & Fre. & 23.7 & 51.6 & 19.1 & 16 & 2.93 & 0.807 & 3 \\
\hline 2 & $\begin{array}{l}\text { I believe that the } \\
\text { discovery of my } \\
\text { daughter's case } \\
\text { was by the } \\
\text { resources room } \\
\text { teacher }\end{array}$ & Fre. & 21.2 & 51.2 & 20.1 & 7.4 & 2.86 & 0.833 & 4 \\
\hline 4 & $\begin{array}{l}\text { I participated with } \\
\text { the resources room } \\
\text { teacher in referring } \\
\text { my daughter }\end{array}$ & Fre. & 23.0 & 46.3 & 24.4 & 18 & 2.86 & 0.843 & 5 \\
\hline & & Total Me & & & & & 2.92 & 0.670 & \\
\hline
\end{tabular}

The results show that there is homogeneity in the participants' satisfaction with the intervention and referral services provided by the resources rooms to their children with learning disabilities. The mean scores ranged from 2.86 to 3.01, and fall within the third point in the 4 - point scale, which is "Agree", according to the study instrument. This clarifies the homogeneity in the agreement on the participants' satisfaction. It is evident in the results that the parents in the present study are satisfied with five of the intervention and referral services provided by the resources rooms to their children with learning disabilities, which are represented by the statements $1,3,5,2$, and 4 .

It is clear that the most prominent feature of parents' satisfaction with the intervention and referral services provided by the resources rooms to their children with learning disabilities is their satisfaction with the appropriateness of their children's pre-referral procedures. This result indicates that there is an interest in facilitating the enrollment of children in the educational resources rooms to reinforce their benefit in the educational process. This, in turn, enhances the parents' satisfaction with the intervention and referral services provided by the resources rooms to their children with learning disabilities, as represented in their satisfaction with the pre-referral procedures to the resources room.

2-Evaluation and Diagnosis Services:

To identify the parents' satisfaction with the evaluation and diagnosis services provided by the resources rooms for their children with learning disabilities, frequencies, percentages, mean scores, standard deviations, and the ranks of the responses of the study sample to the statements of the evaluation and diagnosis service domain have 
been calculated, and the results are illustrated in Table 9.

Table 9. Responses of the participants to the statements of the evaluation and diagnosis services domain in a descending order according to the agreement mean scores

\begin{tabular}{|c|c|c|c|c|c|c|c|c|c|}
\hline \multirow{2}{*}{$\begin{array}{l}\text { Statement } \\
\text { No. }\end{array}$} & \multirow[b]{2}{*}{ Statement } & \multirow{2}{*}{$\begin{array}{l}\text { Frequency } \\
\text { Percentage \% }\end{array}$} & \multicolumn{4}{|c|}{ Degree of Agreement } & \multirow{2}{*}{$\begin{array}{l}\text { Mean } \\
\text { Score }\end{array}$} & \multirow{2}{*}{$\begin{array}{l}\text { Standard } \\
\text { Deviation }\end{array}$} & \multirow[b]{2}{*}{ Rank } \\
\hline & & & $\begin{array}{l}\text { Strongly } \\
\text { Agree }\end{array}$ & Agree & Disagree & $\begin{array}{l}\text { Strongly } \\
\text { Disagree }\end{array}$ & & & \\
\hline \multirow{2}{*}{6} & \multirow{2}{*}{$\begin{array}{l}\text { The tests given to } \\
\text { my daughter were } \\
\text { accurate and } \\
\text { appropriate }\end{array}$} & Fre. & 71 & 135 & 63 & 14 & \multirow[b]{2}{*}{2.93} & \multirow[b]{2}{*}{0.818} & \multirow[b]{2}{*}{1} \\
\hline & & $\%$ & 25.1 & 47.7 & 22.3 & 4.9 & & & \\
\hline \multirow[b]{2}{*}{7} & \multirow{2}{*}{$\begin{array}{l}\text { The diversity of } \\
\text { the tests truly } \\
\text { reflected my } \\
\text { daughter's case }\end{array}$} & Fre. & 59 & 150 & 57 & 17 & \multirow[b]{2}{*}{2.89} & \multirow[b]{2}{*}{0.800} & \multirow[b]{2}{*}{2} \\
\hline & & $\%$ & 20.8 & 53.0 & 20.1 & 6.0 & & & \\
\hline \multirow[b]{2}{*}{12} & \multirow{2}{*}{$\begin{array}{l}\text { The results of the } \\
\text { tests were } \\
\text { satisfactory for me }\end{array}$} & Fre. & 53 & 148 & 65 & 17 & \multirow[b]{2}{*}{2.84} & \multirow[b]{2}{*}{0.796} & \multirow[b]{2}{*}{3} \\
\hline & & $\%$ & 18.7 & 52.3 & 23.0 & 6.0 & & & \\
\hline \multirow[b]{2}{*}{13} & \multirow{2}{*}{$\begin{array}{l}\text { The individual } \\
\text { educational plan } \\
\text { was associated } \\
\text { with the } \\
\text { evaluation results }\end{array}$} & Fre. & 49 & 150 & 69 & 15 & \multirow[b]{2}{*}{2.82} & \multirow[b]{2}{*}{0.775} & \multirow[b]{2}{*}{4} \\
\hline & & $\%$ & 17.3 & 53.0 & 24.4 & 5.3 & & & \\
\hline & $\begin{array}{l}\text { All tests given to } \\
\text { my daughter have }\end{array}$ & Fre. & 55 & 141 & 64 & 23 & & & \\
\hline 10 & $\begin{array}{l}\text { been clarified in } \\
\text { terms of the } \\
\text { content and the } \\
\text { results }\end{array}$ & $\%$ & 19.4 & 49.8 & 22.6 & 8.1 & 2.81 & 0.843 & 5 \\
\hline \multirow[b]{2}{*}{9} & \multirow{2}{*}{$\begin{array}{l}\text { My contribution in } \\
\text { the evaluation has } \\
\text { been essential in } \\
\text { the process of my } \\
\text { daughter's } \\
\text { evaluation }\end{array}$} & Fre. & 55 & 129 & 81 & 18 & \multirow[b]{2}{*}{2.78} & \multirow[b]{2}{*}{0.830} & \multirow[b]{2}{*}{6} \\
\hline & & $\%$ & 19.4 & 45.6 & 28.6 & 6.4 & & & \\
\hline \multirow{2}{*}{11} & \multirow{2}{*}{$\begin{array}{l}\text { I reviewed all the } \\
\text { tests given to my } \\
\text { daughter }\end{array}$} & Fre. & 56 & 126 & 81 & 20 & \multirow{2}{*}{2.77} & & \\
\hline & & $\%$ & 19.8 & 44.5 & 28.6 & 7.1 & & 0.847 & 7 \\
\hline 8 & $\begin{array}{l}\text { I participate in the } \\
\text { evaluation process }\end{array}$ & Fre. & 48 & 127 & 85 & 23 & & & \\
\hline 8 & $\begin{array}{l}\text { which my } \\
\text { daughter received }\end{array}$ & $\%$ & 17.0 & 44.97 & 30.0 & 8.1 & 2.11 & 0.844 & 8 \\
\hline & & Total M & & & & & 2.82 & 0.675 & \\
\hline
\end{tabular}

The results show that there is homogeneity in the participants' satisfaction with the evaluation and diagnosis services provided by the resources rooms to their children with learning disabilities. The mean scores ranged from 2.71 to 2.93, and fell within the third point in the 4-point scale, which is "Agree", according to the study instrument. This clarifies the homogeneity in the agreement on the participants' satisfaction. It is evident in the results that the parents in the present study are satisfied with five of the evaluation and diagnosis services provided by the resources rooms to their children with learning disabilities, which are represented by the statements $6,7,12,13$, and 10 . 
It is clear that the most prominent feature of the parents' satisfaction with the evaluation and diagnosis services provided by the resources rooms to their children with learning disabilities is their contentment with the accuracy and appropriateness of the tests given to their children. This result shows that when children passed the tests, the parents' confidence in their children's capabilities and their ability to learn increased, which in turn improved the parents' satisfaction. Thus, the most prominent feature of the parents' satisfaction with the evaluation and diagnosis services provided by the resources rooms to their children with learning disabilities is their contentment with the accuracy and appropriateness of the tests given to their children.

3-Classroom Environment Services of the Resources Room:

To identify the parents' satisfaction with the classroom environment services provided by the resources rooms for their children with learning disabilities, frequencies, percentages, mean scores, standard deviations, and the ranks of the responses of the study sample to the statements of the domain of classroom environment services of the resources room have been calculated and presented in Table 10 below:

Table 10. Participants' responses to the domain's statements of classroom environment services of the resources room in a descending order according to the agreement mean scores

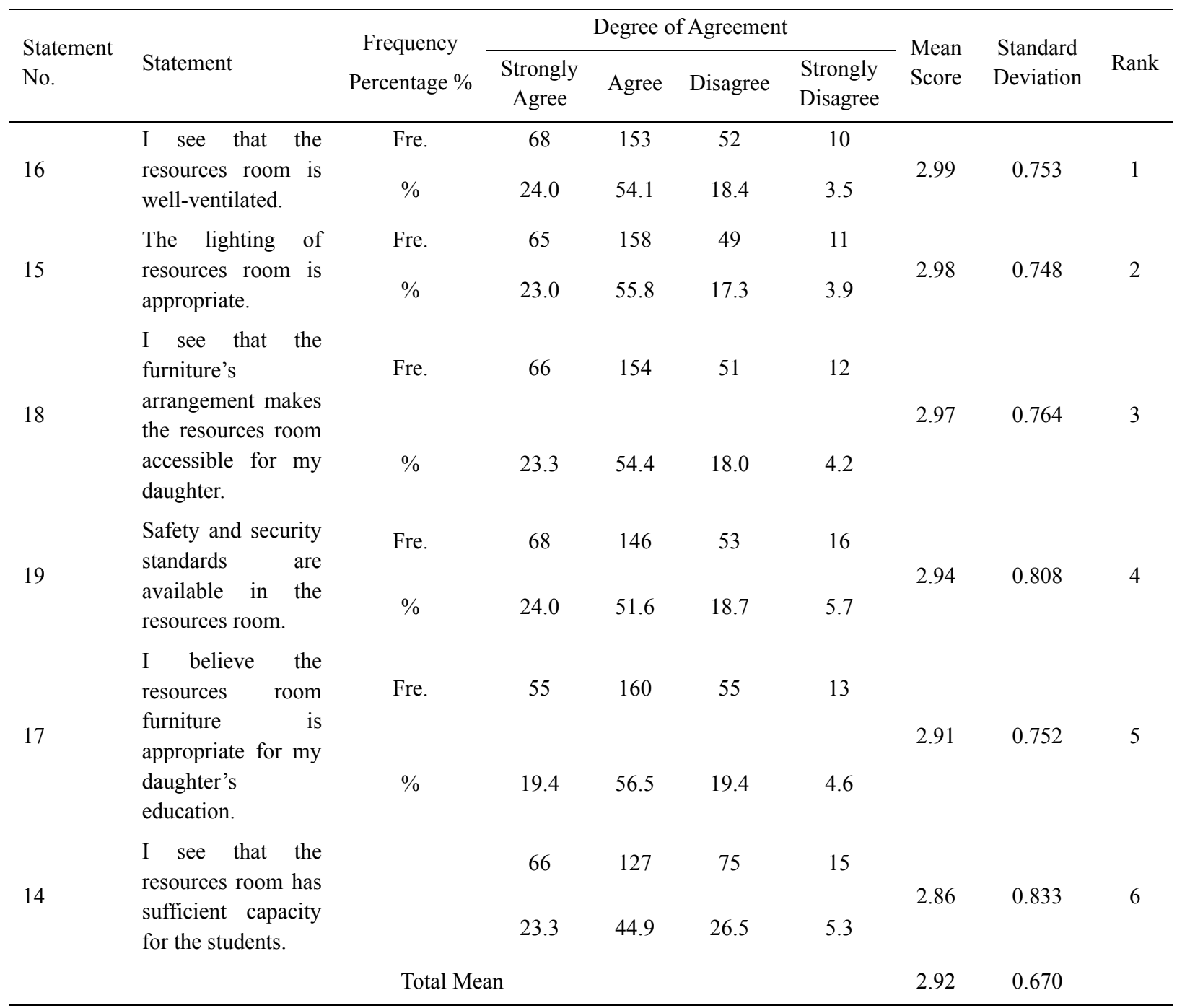

The results show that there is homogeneity in the participants' satisfaction with the with the classroom environment services provided by the resources rooms to their children with learning disabilities. The mean scores ranged from 2.86 to 2.99, and fell within the third point in the 4-point scale, which is "Agree", according to the study instrument. This clarifies the homogeneity in the agreement on the participants' satisfaction. It is evident from the results that the parents in the present study are satisfied with six of the classroom environment 
services provided by the resources rooms to their children with learning disabilities, which are represented by the statements $17,19,18,15$, and 16.

It is clear that the most prominent feature of parents' satisfaction with the classroom environment services provided by the resources rooms to their children with learning disabilities is their contentment with the ventilation of the resources room. This result shows that a good ventilation of the resources room allows the parents to feel that their children are in a good educational environment, which in turn improves the parents' satisfaction. Thus, the most prominent feature of the parents' satisfaction with the classroom environment services provided by the resources rooms to their children with learning disabilities is their contentment with the ventilation of the resources room.

4-Preparation of the Individual Educational Plan Services:

To find out the parents' satisfaction with the Preparation of the Individual Educational Plan services provided by the resources rooms for their children with learning disabilities, frequencies, percentages, mean scores, standard deviations and ranks have been calculated for the responses to the statements of this domain, and the results are presented in Table 11 below:

Table 11. Participants' responses to the domain's statement of planning the individual educational plan services of the resources room in a descending order according to the agreement mean scores

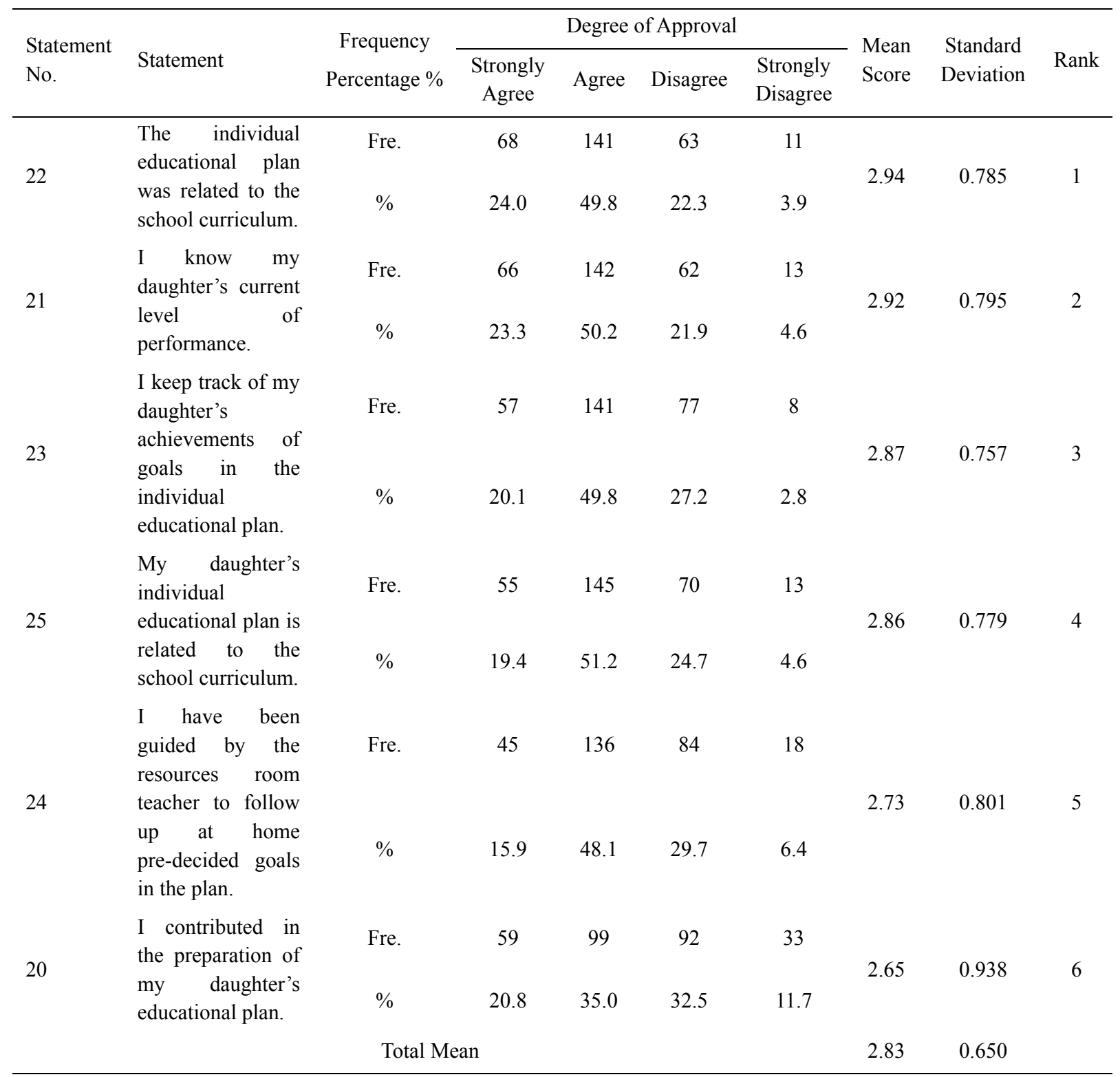


Results show that there is homogeneity in the participants' satisfaction with the services of preparation of an individual educational plan provided by the resources rooms to their children with learning disabilities. The mean scores ranged from 2.65 to 2.94, and fell within the third point in the 4-point scale, which is "Agree", according to the study instrument. This shows the homogeneity in the agreement on the participants' satisfaction with the services of preparation of an individual educational plan provided by the resources rooms to their children with learning disabilities. The results also indicate that the parents in the present study are satisfied with five of the preparation of an individual educational plan services provided by the resources rooms to their children with learning disabilities, which are represented by statements 22, 21, 23, 25, and 24.

Results in Table 11 above show that the most prominent feature of parents' satisfaction with the services of preparation of an individual educational plan provided by the resources rooms to their children with learning disabilities is their contentment with the connection between the individual educational plan and the school curriculum. The connection between the individual's educational plan and the school curriculum allows the parents to feel the ease and the benefit of applying the individual plan on their children, which in turn improves the parents' satisfaction. Thus, the most prominent feature of the parents' satisfaction with the preparation of an individual's educational plan services provided by the resources rooms to their children with learning disabilities is their contentment with the connection between the individual educational plan and the school curriculum.

\section{5-Services provided by the Resources Room Teacher:}

To find out the parents' satisfaction with the services provided by the resources room teacher to their children with learning disabilities, frequencies, percentages, mean scores, standard deviations and ranks have been calculated for the responses of the sample of the study to statements of the domain of services provided by the resources room teacher. Results are shown in Table 12 below:

Table 12. Responses of the participants to the statements of the domain of services provided by the resources room teacher in descending order according to the agreement mean scores

\begin{tabular}{|c|c|c|c|c|c|c|c|c|c|}
\hline \multirow{2}{*}{$\begin{array}{l}\text { Statement } \\
\text { No. }\end{array}$} & \multirow[b]{2}{*}{ Statement } & \multirow{2}{*}{$\begin{array}{c}\text { Frequency } \\
\text { Percentage \% }\end{array}$} & \multicolumn{4}{|c|}{ Degree of Approval } & \multirow{2}{*}{$\begin{array}{l}\text { Mean } \\
\text { Score }\end{array}$} & \multirow[b]{2}{*}{$\begin{array}{c}\text { Standard } \\
\text { Deviation }\end{array}$} & \multirow[b]{2}{*}{ Rank } \\
\hline & & & $\begin{array}{c}\text { Strongly } \\
\text { Agree }\end{array}$ & Agree & Disagree & $\begin{array}{l}\text { Strongly } \\
\text { Disagree }\end{array}$ & & & \\
\hline \multirow[t]{2}{*}{31} & $\begin{array}{l}\text { I see that my } \\
\text { daughter's } \\
\text { education at } \\
\text { the hands of } \\
\text { the resources } \\
\text { room teacher }\end{array}$ & Fre. & 104 & 129 & 41 & 9 & \multirow[t]{2}{*}{3.16} & \multirow[t]{2}{*}{0.785} & \multirow[t]{2}{*}{1} \\
\hline & $\begin{array}{l}\text { has increased } \\
\text { her } \\
\text { motivation to } \\
\text { learn }\end{array}$ & $\%$ & 36.7 & 45.6 & 14.5 & 3.2 & & & \\
\hline \multirow[b]{2}{*}{28} & $\begin{array}{l}\text { The } \\
\text { resources }\end{array}$ & Fre. & 98 & 138 & 41 & 6 & \multirow[b]{2}{*}{3.16} & \multirow[b]{2}{*}{0.743} & \multirow[b]{2}{*}{2} \\
\hline & $\begin{array}{l}\text { room teacher } \\
\text { deals } \\
\text { tactfully with } \\
\text { the families }\end{array}$ & $\%$ & 34.6 & 48.8 & 14.5 & 2.1 & & & \\
\hline \multirow[b]{2}{*}{30} & $\begin{array}{l}\text { My daughter } \\
\text { responds } \\
\text { better to the } \\
\text { resources }\end{array}$ & Fre. & 105 & 124 & 45 & 9 & \multirow[b]{2}{*}{3.15} & \multirow[b]{2}{*}{0.798} & \multirow[b]{2}{*}{3} \\
\hline & $\begin{array}{l}\text { room teacher } \\
\text { than the } \\
\text { regular } \\
\text { classroom } \\
\text { teacher. }\end{array}$ & $\%$ & 37.1 & 43.8 & 15.9 & 3.2 & & & \\
\hline
\end{tabular}




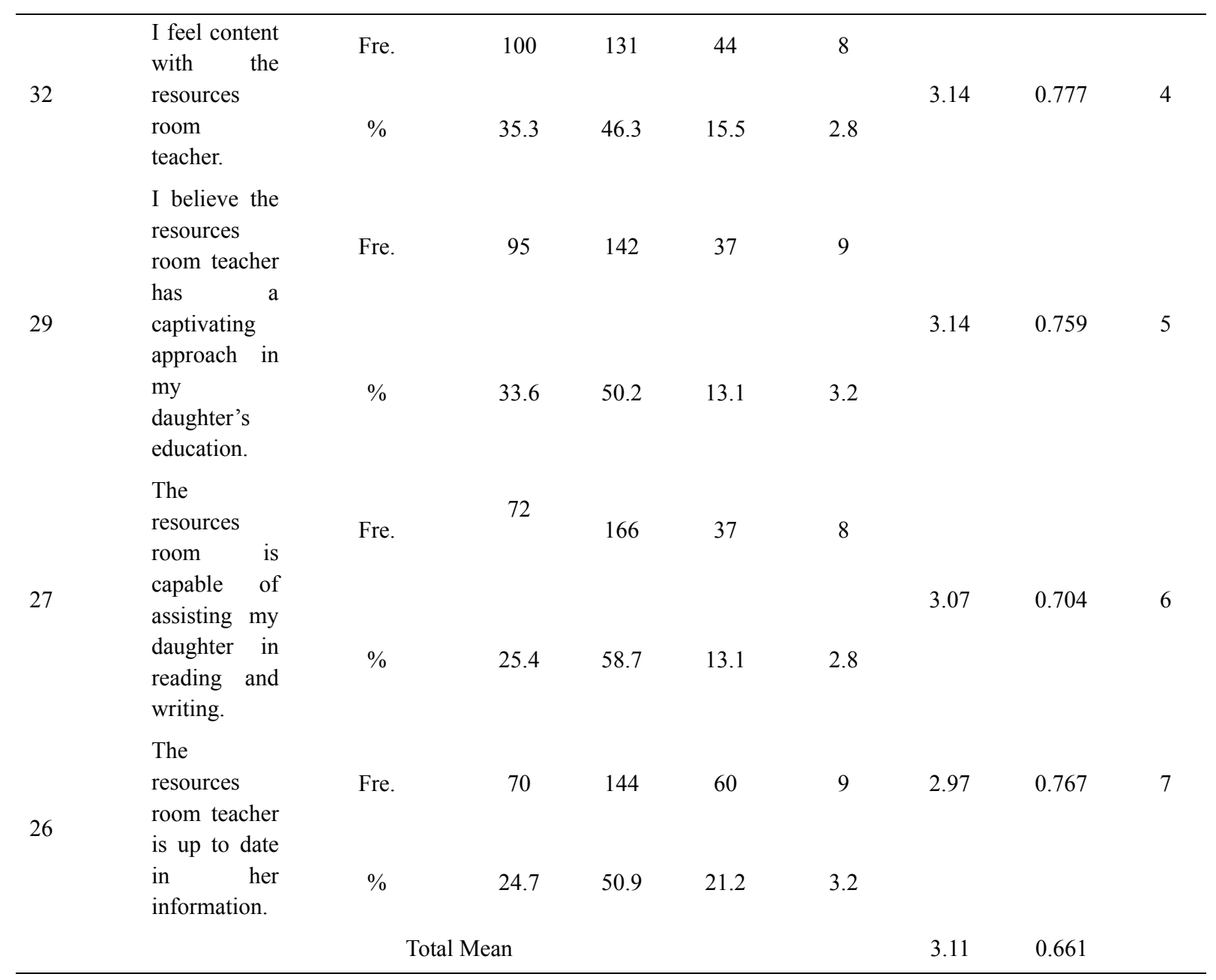

Table 12 shows that there is a homogeneity in the participants' satisfaction with the services provided by the resources room's teacher to their children with learning disabilities. The mean scores ranged from 2.97 to 3.16 , and fell within the third point in the 4- point scale, which is "Agree", according to the study instrument. This shows the homogeneity in the agreement on the participants' satisfaction with the services provided by the resources rooms to their children with learning disabilities. The results also show that the parents are satisfied with seven of the services provided by the resources room teacher to their children with learning disabilities, most notably are the services mentioned in statements $31,28,30,32$, and 29.

The results in Table 12 above show that most clear feature of parents' satisfaction with the services provided by the teacher of resources room to their children with learning disabilities is their contentment with the teacher's reinforcement of their children's motivation to learn. This shows that the teacher's reinforcement of the children's motivation to learn makes the parents feel that their children are capable of learning, and improving their academic achievement, which in turn improves the parents' level of satisfaction. Thus, the most prominent feature of the parents' satisfaction with services provided by the resources room teacher to their children with learning disabilities is their contentment with the reinforcement the teacher provides for their children's motivation to learn.

6-Follow-up services with the parents:

To find out the parents' satisfaction with the follow-up services provided by the resources room to their children with learning disabilities, frequencies, percentages, mean scores, standard deviations, and ranks have been calculated for the parents' responses to statements of the domain of follow-up services provided by the resources room. Results are shown in Table 13 below: 
Table 13. Participants' responses to the domain's statement of follow-up services provided by the resources room in a descending order according to the agreement mean scores

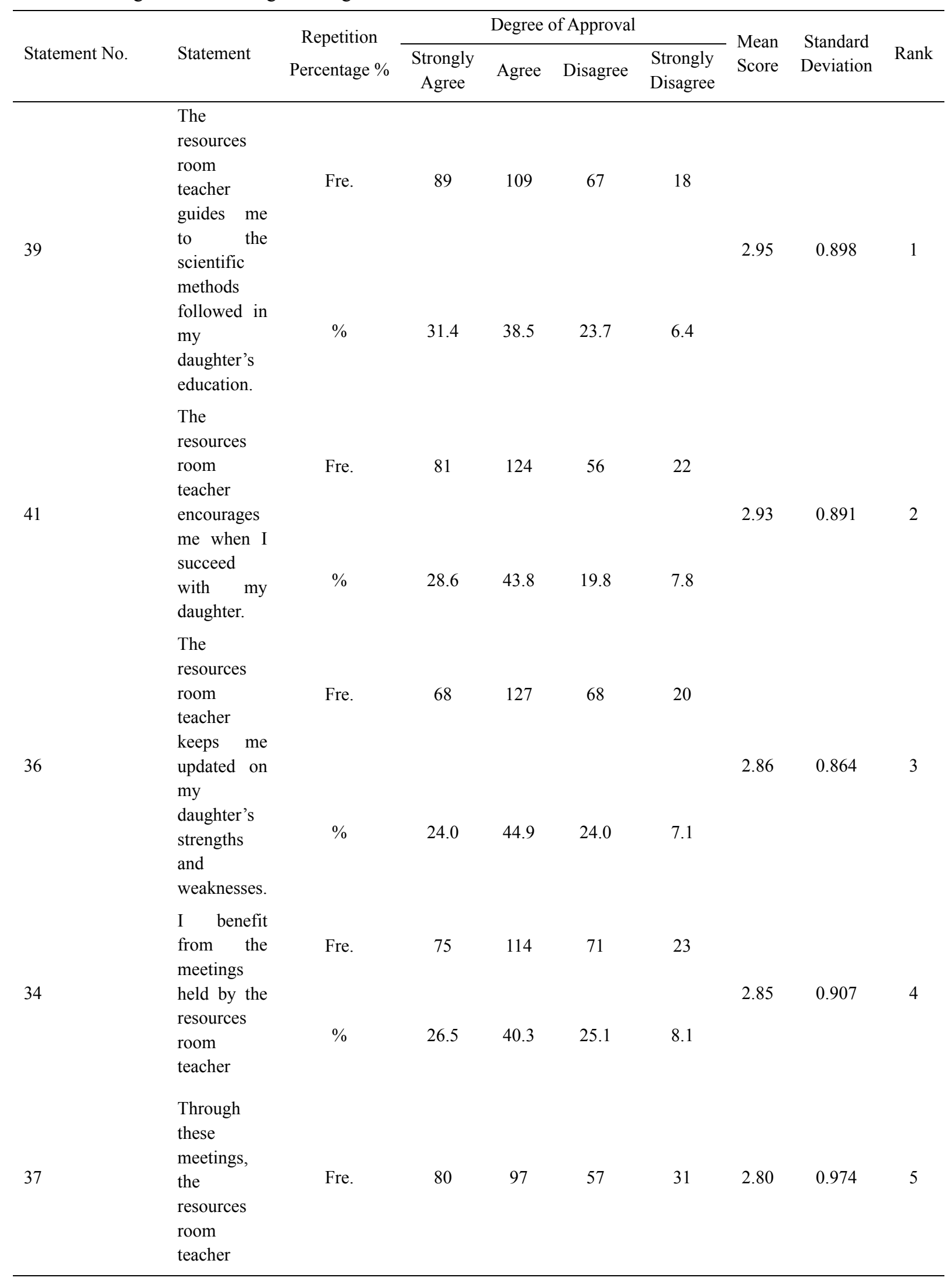




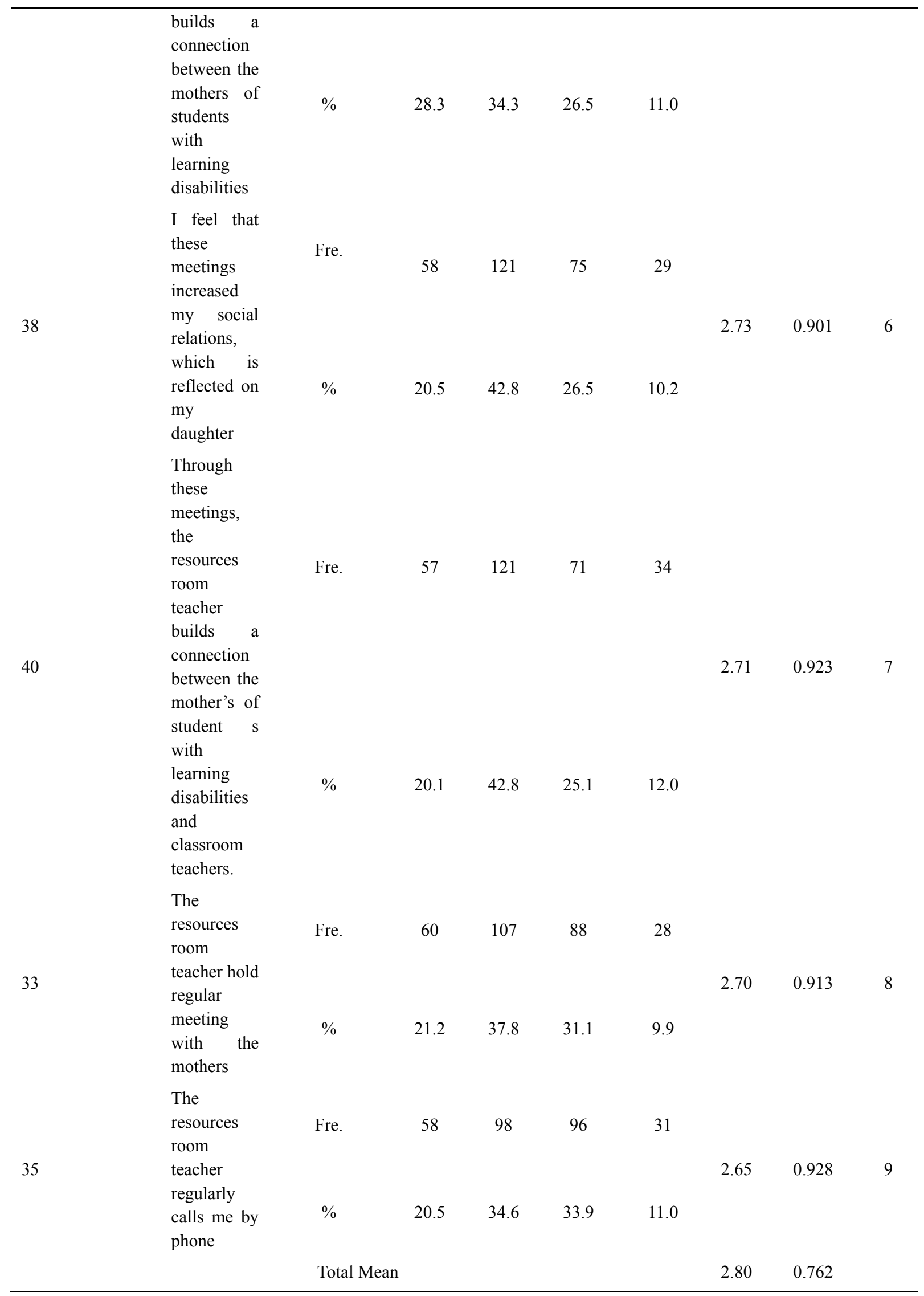


Table 13 above shows that there is a similarity in the participants' satisfaction with the follow-up services provided by the resources room to their children with learning disabilities. The mean scores ranged from 2.65 to 2.95 , and fell within the third point in the 4 - point scale, which is "Agree", according to the instrument of the study. This shows the homogeneity in the agreement on the participants' satisfaction with the follow-up services provided by the resources rooms to their children with learning disabilities. The results also show that the parents are satisfied with nine of the follow-up services provided by the resources room teacher to their children with learning disabilities, most notably the services mentioned in statements 37, 34, 36, 41, and 39.

Table 13 above shows that most prominent feature of parents' satisfaction with the follow-up services provided by the resources room to their children with learning disabilities is their contentment with the teacher's guidance for them on scientific methods used in their children's education. This shows that the teacher's guidance for the parents on the scientific methods used in their children's education makes them to feel the ease of practicing their role in their children's education, which in turn improves the parents' level of satisfaction. Thus, the most prominent feature of the parents' satisfaction with follow-up services provided by the resources room to their children with learning disabilities is their contentment with resources room teacher's guidance for them on the scientific methods used in their children's education.

\section{7-Extracurricular Services:}

To find out the parents' satisfaction with the extracurricular services provided by the resources room to their children with learning disabilities, frequencies, percentages, mean scores, standard deviations, and ranks have been calculated for the parents' responses to statements of the domain of extracurricular services provided by the resources room. Results are shown in Table 14 below:

Table 14. Participants' responses to the domain's statement of extracurricular services of the resources room in descending order according to the agreement mean scores

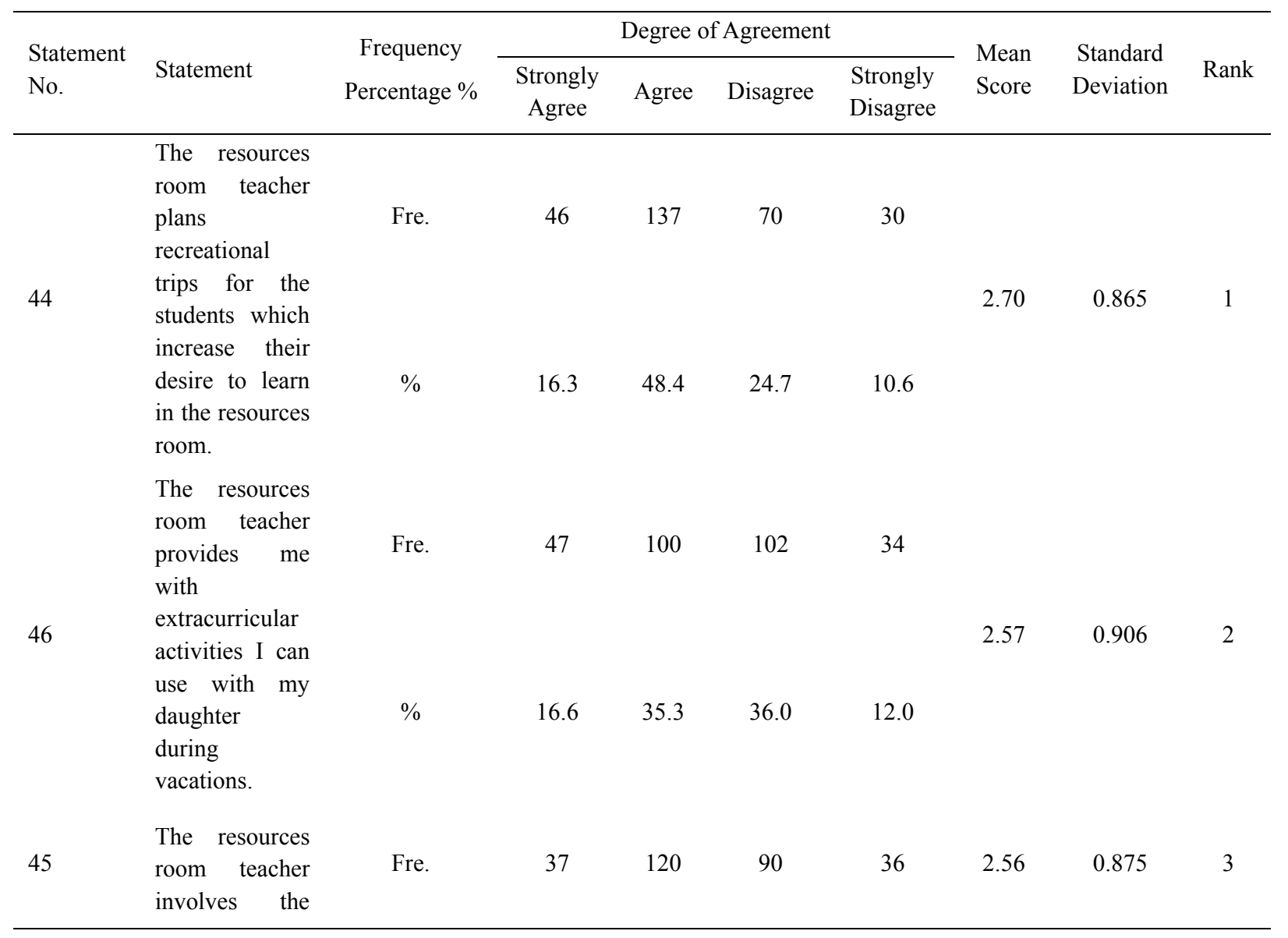




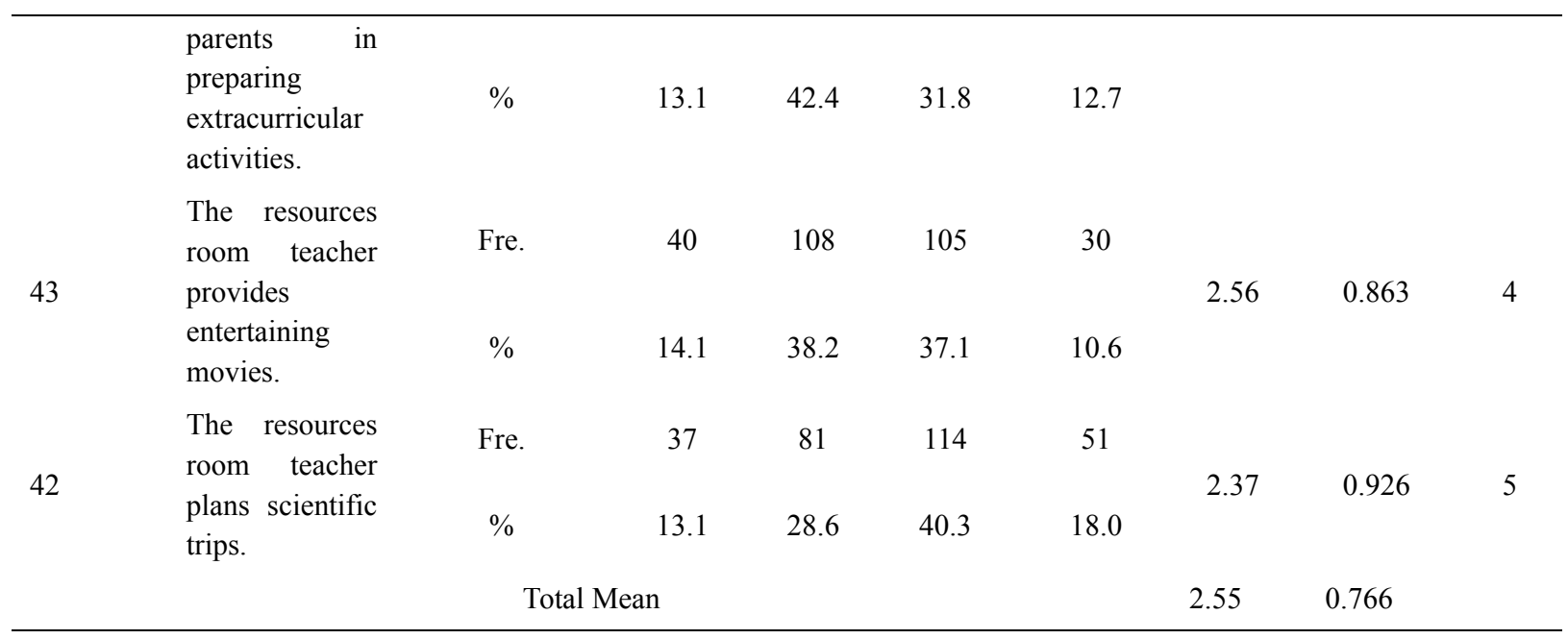

Table 14 above shows that there is a variation in the participants' satisfaction with the extracurricular services provided by the resources room to their children with learning disabilities. The mean scores ranged from 2.37 to 2.70 , and fell in the second and third categories of the 4-scale categories of agree and disagree, according to the instrument of the study. This shows differences in the agreement on the participants' satisfaction with the extracurricular services provided by the resources rooms to their children with learning disabilities. The results also indicate that the parents are satisfied with only 4 of the extracurricular services provided by the resources room to their children with learning disabilities, most notably are the services mentioned in statements $43,45,46$, and 44 .

Table 14 above shows that the participating parents did not show satisfaction with the extracurricular services provided by the resources room to their children with learning disabilities, which is clearly manifested in statement 42 "The resources room teacher plan scientific trips", with a mean score of 2.37 out of 4 . The results also show that the most prominent feature of the parents' satisfaction with the extracurricular services provided by the resources room to their children with learning disabilities is in their contentment with the teacher's planning of recreational parties, which increases students' desire to learn in this room. This makes the parents feel that their children's integration into the teaching process, which in turn improves the parents' satisfaction with extracurricular services provided by the resources room to their children with learning disabilities. This is clearly stated in their contentment with the teacher's planning of entertaining parties that improve the students' desire to learn inside the resources room.

\section{8-Training Services:}

To find out the parents' satisfaction with the training services provided by the resources room to their children with learning disabilities, frequencies, percentages, mean scores, standard deviations, and ranks have been calculated for the parents' responses to statements of the domain of the training services provided by the resources room. Results are shown in Table 15 below:

Table 15. Participants' responses to the training services' domain provided by the resources room in a descending order according to the agreement mean scores

\begin{tabular}{|c|c|c|c|c|c|c|c|c|c|}
\hline \multirow{2}{*}{$\begin{array}{l}\text { Statement } \\
\text { No. }\end{array}$} & \multirow[b]{2}{*}{ Statement } & \multirow{2}{*}{$\begin{array}{c}\text { Frequency } \\
\text { Percentage \% }\end{array}$} & \multicolumn{4}{|c|}{ Degree of Agreement } & \multirow{2}{*}{$\begin{array}{l}\text { Mean } \\
\text { Score }\end{array}$} & \multirow{2}{*}{$\begin{array}{l}\text { Standard } \\
\text { Deviation }\end{array}$} & \multirow[b]{2}{*}{ Rank } \\
\hline & & & $\begin{array}{c}\text { Strongly } \\
\text { Agree }\end{array}$ & Agree & Disagree & $\begin{array}{l}\text { Strongly } \\
\text { Disagree }\end{array}$ & & & \\
\hline 50 & $\begin{array}{l}\text { I am } \\
\text { satisfied } \\
\text { with the } \\
\text { guidance } \\
\text { services }\end{array}$ & Fre. & 51 & 133 & 69 & 30 & 2.72 & 0.880 & 1 \\
\hline
\end{tabular}




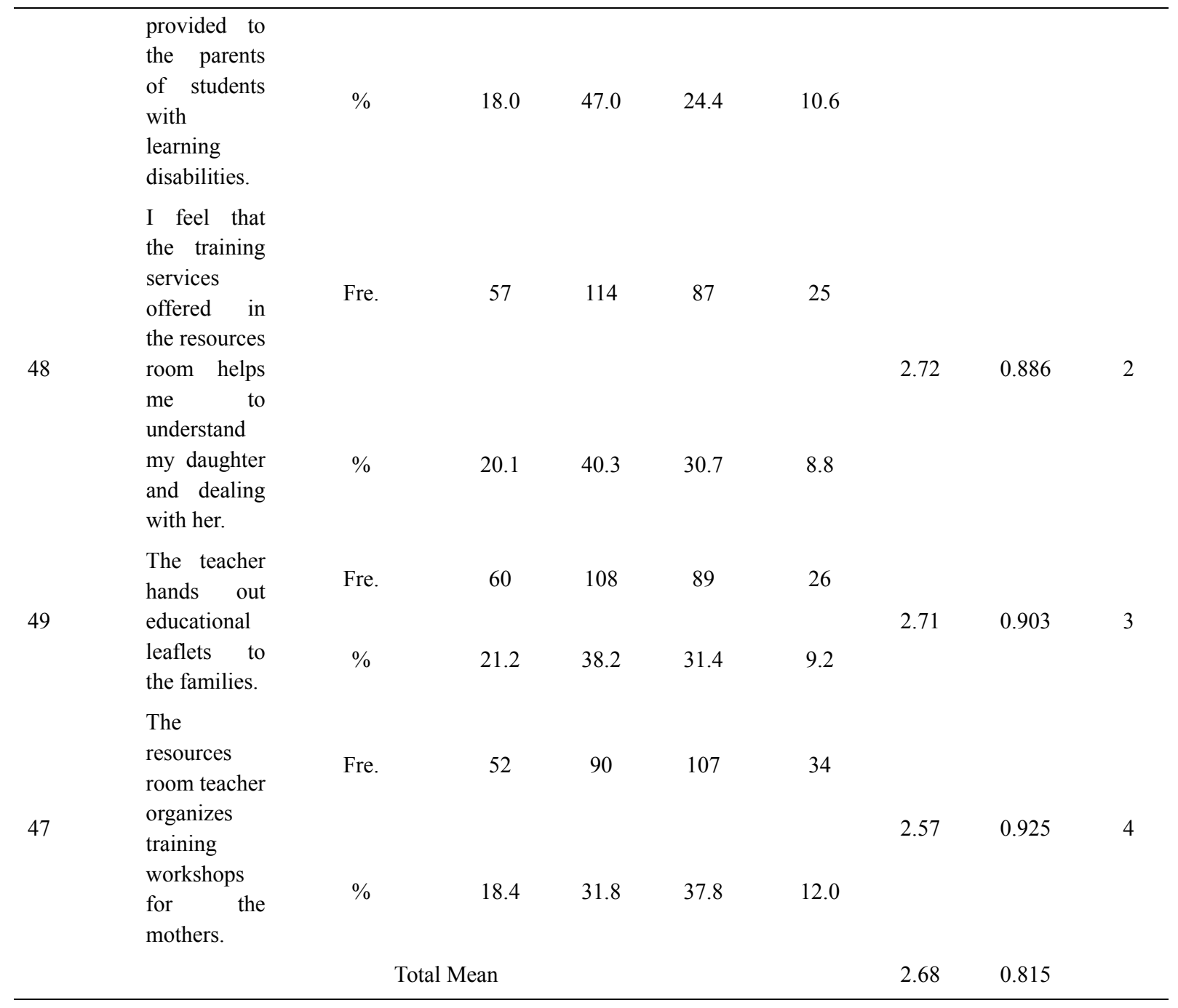

Table 15 above shows that there is sameness in the participants' satisfaction with the training services provided by the resources room to their children with learning disabilities. The mean scores ranged from 2.57 to 2.72 , and fell within the third point in the 4-point scale of 'Agree', according to the instrument of the study. This shows homogeneity in the agreement on the participants' satisfaction with the training services provided by the resources rooms to their children with learning disabilities. It is also shown that the parents are satisfied with four of the training services provided by the resources room to their children with learning disabilities, most notably are the services mentioned in statements $47,49,48$, and 50 .

The table also shows that most prominent feature of parents' satisfaction with the training services provided by the resources room to their children with learning disabilities is their contentment with the guidance services offered for the students' parents. This shows that guidance services provided for the parents help them to understand their children's status, which in turn improves the parents' level of satisfaction. Thus, the most prominent feature of the parents' satisfaction with the training services provided by the resources room to their children with learning disabilities is manifested in the parents' contentment with the guidance services offered to them by the resources room.

\section{9-Behavioral Therapy Services:}

To find out the parents' satisfaction with the behavioral therapy services provided by the resources room to their children with learning disabilities, frequencies, percentages, mean scores, standard deviations, and ranks have been calculated for the parents' responses to statements of the domain of behavioral therapy services provided by the resources room. Results are shown in Table 16 below: 
Table 16. Participants' responses to the domain statements of behavioral therapy services provided by the resources room in a descending order according to the agreement mean scores

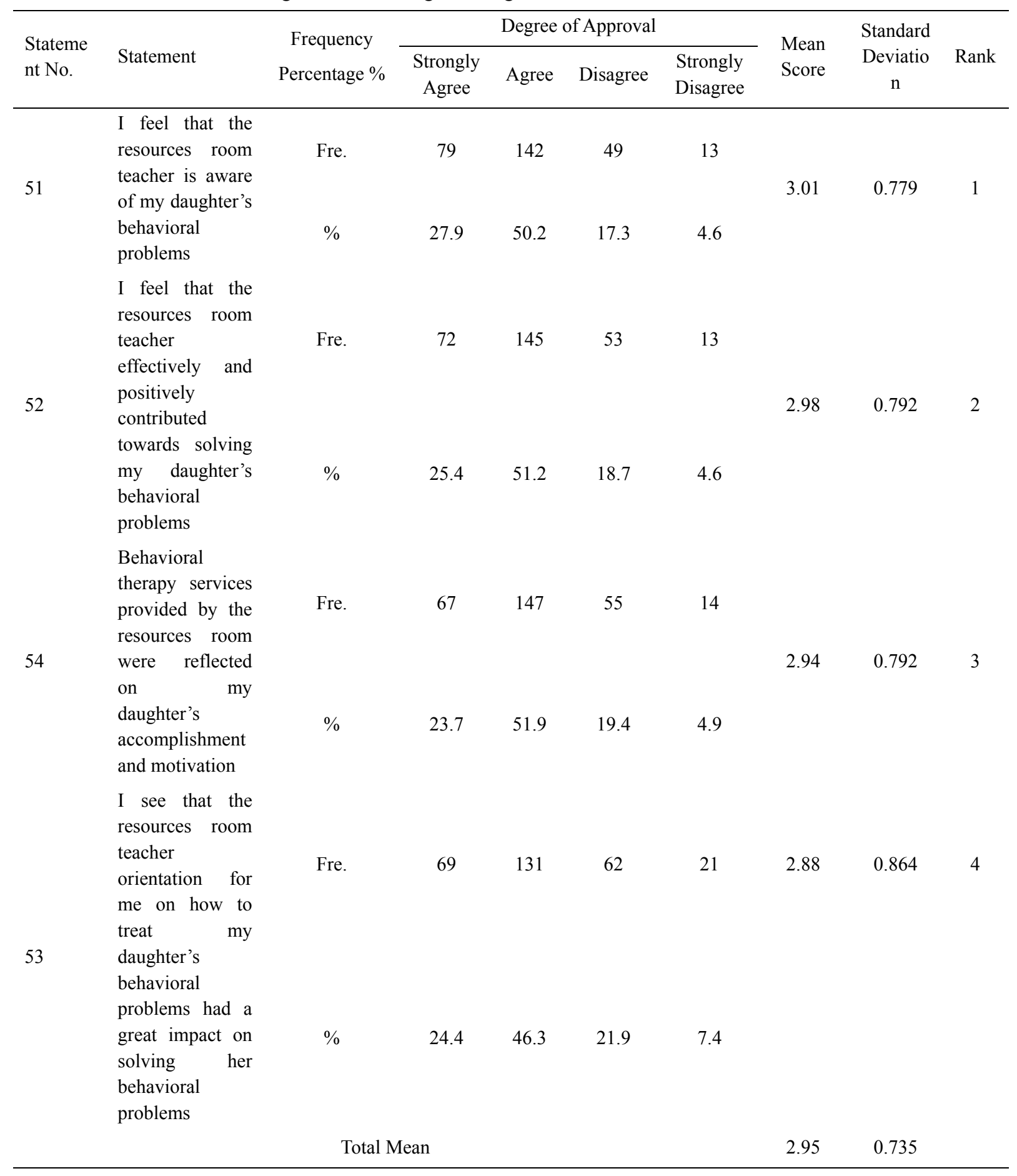

Table 16 above shows that there is homogeneity in the participants' satisfaction with the behavioral therapy services provided by the resources room to their children with learning disabilities. The mean scores ranged from 2.88 to 3.01, and fell within the third point in the 4-point scale of 'Agree', according to the instrument of the study. This shows homogeneity in the agreement on the participants' satisfaction with the behavioral therapy services provided by the resources rooms to their children with learning disabilities. It is also shown that the parents are satisfied with four of the behavioral therapy services provided by the resources room to their children with learning disabilities, most notably are the services mentioned in statements 53, 54, 52, and 51.

The table also shows that most prominent feature of parents' satisfaction with the behavioral therapy services 
provided by the resources room to their children with learning disabilities is their contentment with the resources room teacher's recognition of their children's behavioral problems. This indicates that the resources room teacher's recognition of the children's behavioral problems enhances the parents' confidence in solving their children's behavioral problems, which in turn improves the parents' level of satisfaction. Thus, the most prominent feature of the parents' satisfaction with the behavioral therapy provided by the resources room to their children with learning disabilities is their contentment with the resources room teacher's recognition of the children's behavioral problems. .

10-Services related to the means and methods used:

To identify the parents' satisfaction with services related to the used methods, means, and services in the resources room to their children with learning disabilities, frequencies, percentages, mean scores, standard deviations, and ranks have been calculated for the parents' responses to the statements of the domain of services related to the used means and methods provided by the resources room. Results are shown in Table 17 below:

Table 17. Participants' responses to the services domain statements related to the used means and methods in the resources room in a descending order according to the agreement mean scores

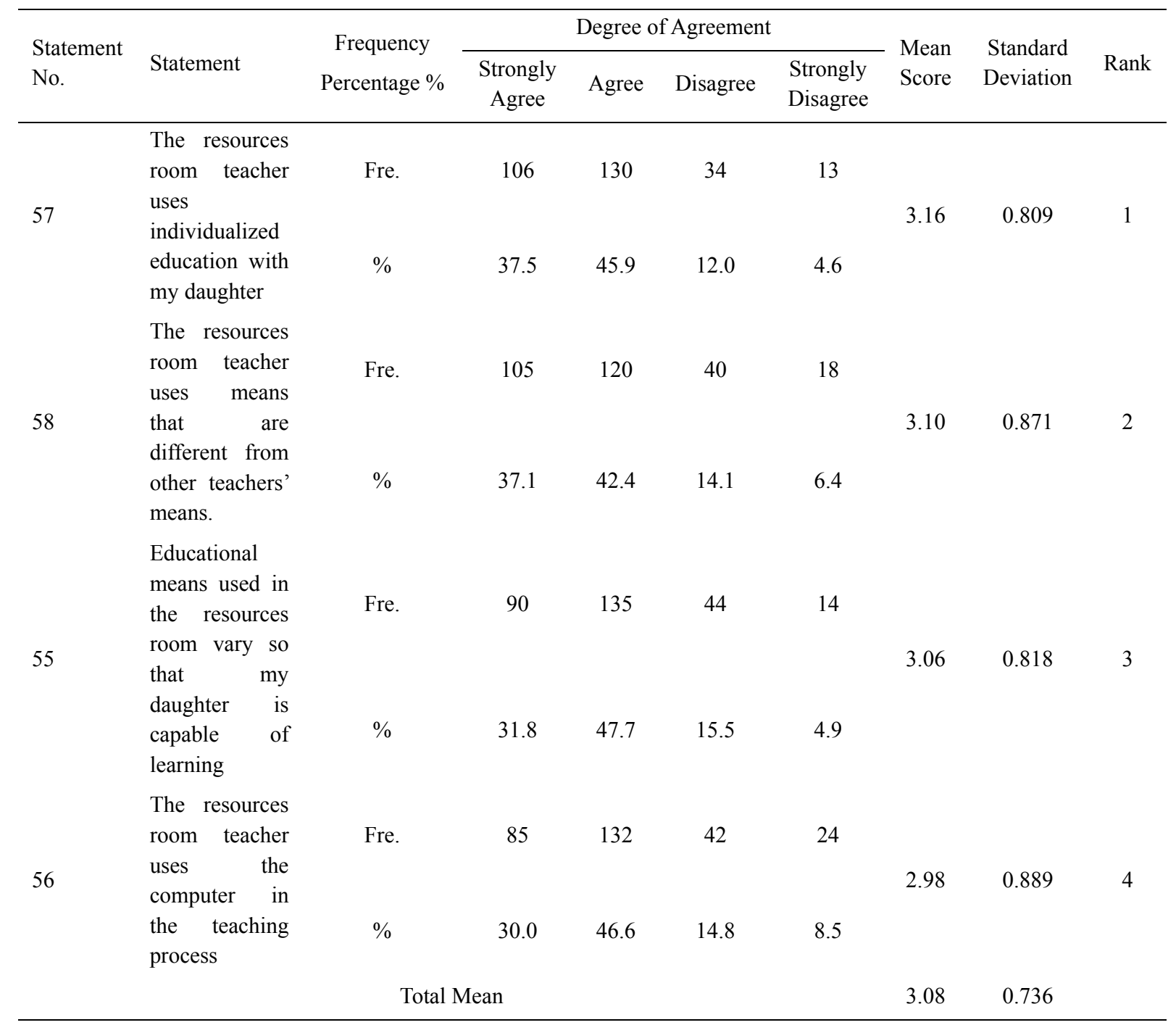

Table 17 above shows that there is a consistency in the participants' satisfaction with services related to the used means and the methods provided by the resource rooms with a mean score of 3.08 out of 4.00 . This mean score fell in the third category of 4-scale of 'Agree', which ranged from 2.51 to 3.25. It is shown in the results that the participating parents in the study agree with four of the services related to the used means and methods provided by the resources room for their children with learning disabilities, most notably the services mentioned in 
statements $57,58,56$, and 55 .

The table also shows that most prominent feature of parents' satisfaction with the services related to the used means and methods which are provided by the resources room to their children with learning disabilities their contentment with the resources room teacher's use of individualized education. This result shows that the resources room teacher's use of individualized learning with the students makes the parents feel that their children are getting adequate attention, which in turn improves the parents' level of satisfaction. Thus, the most prominent feature of the parents' satisfaction with services related to used means and methods which are provided by the resources room to their children with learning disabilities is their contentment with the resources room teacher's use of individualized education with their children.

To sum up, the study showed that there is a generalized satisfaction, although not high for the services provided to female students with learning disabilities in the resources rooms. This satisfaction varied according to the study variables as the child's grade of the student, educational level of the guardian, the number of members with learning disabilities within a family, and the number of years the student spent in the resources room.

The results showed that the services provided by the Resource Room teacher had a mean score of (3.11), followed by behavioral therapy services with a mean score of (2.95), while the methodology services had the lowest parents' satisfaction with a mean score of (2.55).

The results also indicate a variation in the parents' satisfaction, which can be considered realistic to a great extent. The services provided by the resources teacher scored the highest percentage, which clearly indicates the importance of the role played by resources room teachers compared to that of the regular teachers. As a result, the resources room teacher has a high and tangible role in the parents' view as the resources room teachers are in continuous contact with the parents from the beginning of the diagnosis process, through the educational process, and ending with evaluation. Having close contact with the parents and informing them about their child's improvement in each stage is considered one of the most important roles of the special education teacher. The results are consistent with those of Bairat (2005), Bairat and Al-Zeraiqat (2012), Lange and Lehr (2000), Siebes (2006), Campbell (1995), Larter (1986), and Phillips (1990).

\section{Recommendations}

In light of the findings of the present research, some pedagogical implications can be presented to decision makers to improve the resources room which leads to an increase of the parents' satisfaction. These include:

1) Activation of the parents of female students with learning difficulties. This can be done as follows.

- Involving parents in evaluation and decision-making processes.

- Involving parents in the creation and implementation of the individual educational plans.

- Following up parents' suggestions regarding improving resources room services.

- Communicating constantly and developing relationships with resources room teachers in a way that reflects positively on the students.

2) Continuous follow-up with parents-especially with the newly discovered cases-through:

- Providing advice and guidance to help them accept the case.

- Participating in workshops to develop skills to deal with cases.

- Directing parents to sources of information in libraries and on the internet.

- Providing psychological or social counseling for families with multiple cases or low educational levels.

3) Activate the role of resources room teachers through:

- Educating school workers and parents in the field of learning disabilities and the services provided by the resources rooms.

- Adopting the cases of female students with learning difficulties and enlighten school boards about them.

- Providing advice to regular classroom teachers of female students with learning difficulties regarding methods of teaching, follow-up, and evaluation.

- Referring families with multiple cases to psychological and social services.

\section{Acknowledgements}

This is a research project that was supported by a grant from the Research Center for the Humanities, Deanship of Scientific Research at King Saud University. 


\section{References}

Abunyan, I. (2007). Demanding the Arab family partnership in the services of children with disability. Paper presented at the First Scientific Conference, Department of Psychology, Banha University, Egypt, $14-15 / 7 / 2007$.

Abunyan, I. (2012). Learning difficulties' teaching methods and cognitive strategies (Issue 2). Riyadh: The International House for Publishing and Distribution.

Al-Assaf, S. (2006). The entrance for researchers in behavioral sciences (4th ed.), Al Obeikan for Publishing and Distribution, Riyadh.

Al-Hadidi, M. (2003). Problems facing teachers of resources rooms in Jordan. Journal of Arab Academy for Special Education.

Al-Khatib, J., \& Al-Hadidi, M. (2003). Current issues in special education. Arab Academy for Special Education, Riyadh, Saudi Arabia.

Al-Mousa, N. (1999). Special education history in the Ministry of Education in the shadows of the centenary of founding. Saudi Arabia, Ministry of Education.

Al-Rousan, F. (2001). The Psychology of up-normal children (5th ed.). Amman, Jordan, Al-Fikr Al-Arabic for Publishing and Distribution.

Al-Sartawi, Z., \& Abunyan, I. (1998). Resources Rooms-Teachers' Guide in special education (Translated). King Saud University, Saudi Arabia.

Awwad, M., \& Al Imam, M. (2007). The reality of the educational services presented for learning difficulties 'students in the Jordanian resources rooms. Paper presented at the $14^{\text {th }}$ Annual Conference-Center of Psychological Counseling, Ain Shams University, 591-631.

Ayed, W. (2012). The degree of satisfaction of parents of students with learning difficulties about services provided to them in the Resources Rooms in Amman. Journal of Humanities and Administrative Sciences, MAJMAAH University, Issue 1. Retrieved from http://faculty.mu.edu.sa/download.php?fid=16866

Bairat, M., \& Al-Zraiqat, I. (2012). The degree of satisfaction of parents of children with learning difficulties for their children integration in public schools. Journal of the Association of Arab Universities for Education and Psychological Sciences, Syria, 10(3), 229-250.

Crockett, J., \& Kauffman, J. (1999). The least restrictive environment: Its origins and interpretations in special education. Mahwah, NJ: Lawrence Erlbaum Associates.

Frend, M., \& Bursuck, W. (2002). Including Students with Special Needs. Allyn and Bacon. USA.

Gallagher, J. (1995). Lesson Learned From the Implementation of the IEP: Application to the IFSP. Topic in Early Children Special Education, 15(3), 353-379.

Jaffe, J., \& Segal, J. (2005). Post-traumatic stress disorder (PTSD): Symptoms, types and treatment. Help guide Mental Health Issues. Retrieved from http://www.helpguide.org/mental/post_traumatic_stress_disorder_ symptoms_treatment.htm

Lange, C., \& Lehr, C. (2000). Charter Schools and students with disabilities. Remedial and Special Education, 21(3), 141-151. http://dx.doi.org/10.1177/074193250002100303

Latter, S. (1986). Identification, placement and review process Parent Guardians Options Handicapped a gifted children code. Retrieved from http //:bubaline.nick.com/scripts/login dii/ 082004065301-29

Lerner, J. (2000). Learning Disabilities Theories Diagnosis and Teaching Strategies (8th ed.). New York: by Houghton Mifflin Company Boston.

McNamar, B. (1998). Teacher Consultation: The Key to A Successful Resource room Program. Perceptions (Vol. 5).

Mercer, C. (1997). Students With Learning Disabilities (5th ed.). Merrill an Imprint Saddle River, New Jersey, USA.

Smith, D. (2004). Introduction to Special Education. Boston: Allyn and Bacon. Specialized Support and Disability Services, website-University of Alberta.

Spann, S., Kohler, F., \& Soenksen, D. (2003). Examining parents' involvement in and perceptions of special education services: An interview with families in a parent support group. Focus on Autism and Other 
Developmental Disabilities, 18(4), 228-237. http://dx.doi.org/10.1177/10883576030180040401

Stephenson, P. (1992). Perspectives of mother Whose Children Are in special day classes for learning disabilities. Journal of learning disabilities, 25(8), 539-543. http://dx.doi.org/10.1177/002221949202500809

\section{Appendix}

In the name of Allah, the most Gracious, The most merciful

Dear Parent

Greetings,

The current tool aims to determine the level of satisfaction of parents of female students with learning disabilities with the services provided in the resources room. We thank you for your precious time hoping that you answer the following questions. Note that all that is included will be used for purposes of scientific research.

Please fill in the following information by placing $(\mathrm{x})$ in the proper place, noting that the information will be confidential.

Student's Grade

- Nature of relationship with the student:

Father (

Mother (

Other (

- Educational level of guardian:

Elementary or less

Intermediate (

High school

Diploma (

BA (

Graduate studies (

- Nature of the family :

Family with a normal child (

Family with a case of learning disabilities

- Number of family members with learning difficulties or disabilities:

1

2

3(

4(

- Time spent by the child in the resources room:

One- Two years (

Three years ( 
Longer periods

\begin{tabular}{|c|c|c|c|c|c|}
\hline No. & Statements & $\begin{array}{c}\text { Strongly } \\
\text { Agree }\end{array}$ & Agree & Disagree & $\begin{array}{l}\text { Strongly } \\
\text { Disagree }\end{array}$ \\
\hline \multicolumn{6}{|c|}{ Intervention and Referral Services } \\
\hline 1 & $\begin{array}{l}\text { The referral procedure of my daughter to the } \\
\text { resources room came at the right time. }\end{array}$ & & & & \\
\hline 2 & $\begin{array}{l}\text { My daughter's case was discovered by the } \\
\text { resources room teacher. }\end{array}$ & & & & \\
\hline 3 & $\begin{array}{l}\text { The classroom teacher played a role in my } \\
\text { daughter's referral. }\end{array}$ & & & & \\
\hline 4 & $\begin{array}{l}\text { I participated in the referral of my daughter with the } \\
\text { resources room teacher. }\end{array}$ & & & & \\
\hline 5 & $\begin{array}{l}\text { Appropriate tests have been used to discover my } \\
\text { daughter's case. }\end{array}$ & & & & \\
\hline \multicolumn{6}{|c|}{ Evaluation and Diagnosis Services } \\
\hline 6 & $\begin{array}{l}\text { The tests given to my daughter were accurate and } \\
\text { appropriate. }\end{array}$ & & & & \\
\hline 7 & $\begin{array}{l}\text { The diversity of the tests has given a true reflection } \\
\text { of my daughter's case. }\end{array}$ & & & & \\
\hline 8 & $\begin{array}{l}\text { I participated in the evaluation process my daughter } \\
\text { received. }\end{array}$ & & & & \\
\hline 9 & $\begin{array}{l}\text { My contribution in the evaluation has been essential } \\
\text { in the process of my daughter's evaluation. }\end{array}$ & & & & \\
\hline 10 & $\begin{array}{l}\text { All tests given to my daughter have been clarified } \\
\text { according in terms of the content and meaning of } \\
\text { the results. }\end{array}$ & & & & \\
\hline 11 & I reviewed all the tests given to my daughter. & & & & \\
\hline 12 & The tests' results were satisfactory for me & & & & \\
\hline 13 & $\begin{array}{l}\text { The individual educational plan was related to the } \\
\text { evaluation results. }\end{array}$ & & & & \\
\hline \multicolumn{6}{|c|}{ Classroom Environment of the Resources Room Services } \\
\hline 14 & $\begin{array}{l}\text { The resources room has sufficient capacity for the } \\
\text { students present in it. }\end{array}$ & & & & \\
\hline 15 & The lighting of resources room is appropriate. & & & & \\
\hline 16 & The resources room has good ventilation. & & & & \\
\hline 17 & $\begin{array}{l}\text { The furniture in the resources room is suitable for } \\
\text { my daughter's education. }\end{array}$ & & & & \\
\hline 18 & $\begin{array}{l}\text { The furniture arrangement in the resources room } \\
\text { makes it accessible for my daughter. }\end{array}$ & & & & \\
\hline 19 & $\begin{array}{l}\text { Safety and security standards are available in the } \\
\text { resources room. }\end{array}$ & & & & \\
\hline \multicolumn{6}{|c|}{ Preparation of the individual educational Plan services } \\
\hline 20 & $\begin{array}{l}\text { I contributed in the preparation of my daughter's } \\
\text { educational plan. }\end{array}$ & & & & \\
\hline
\end{tabular}




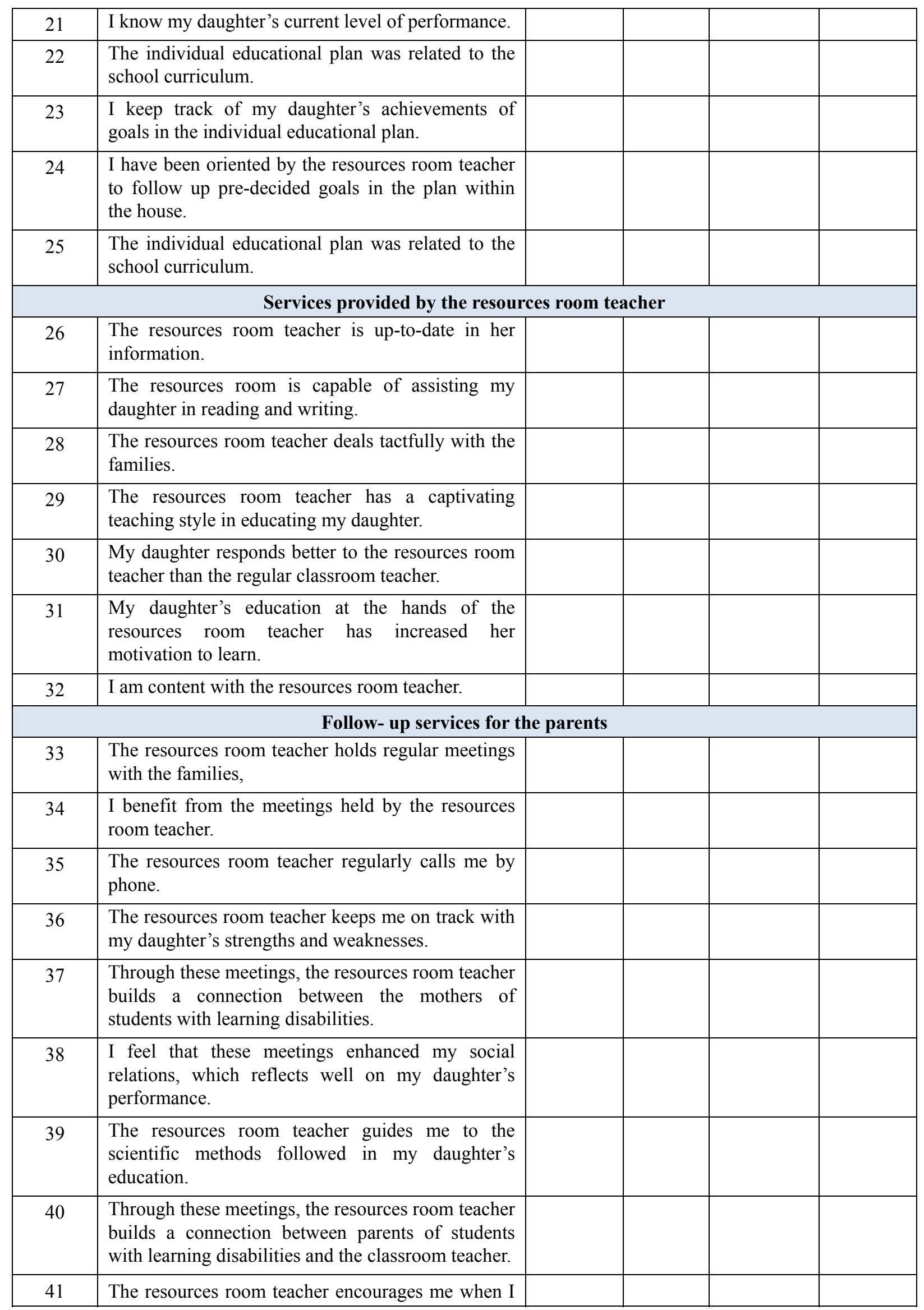




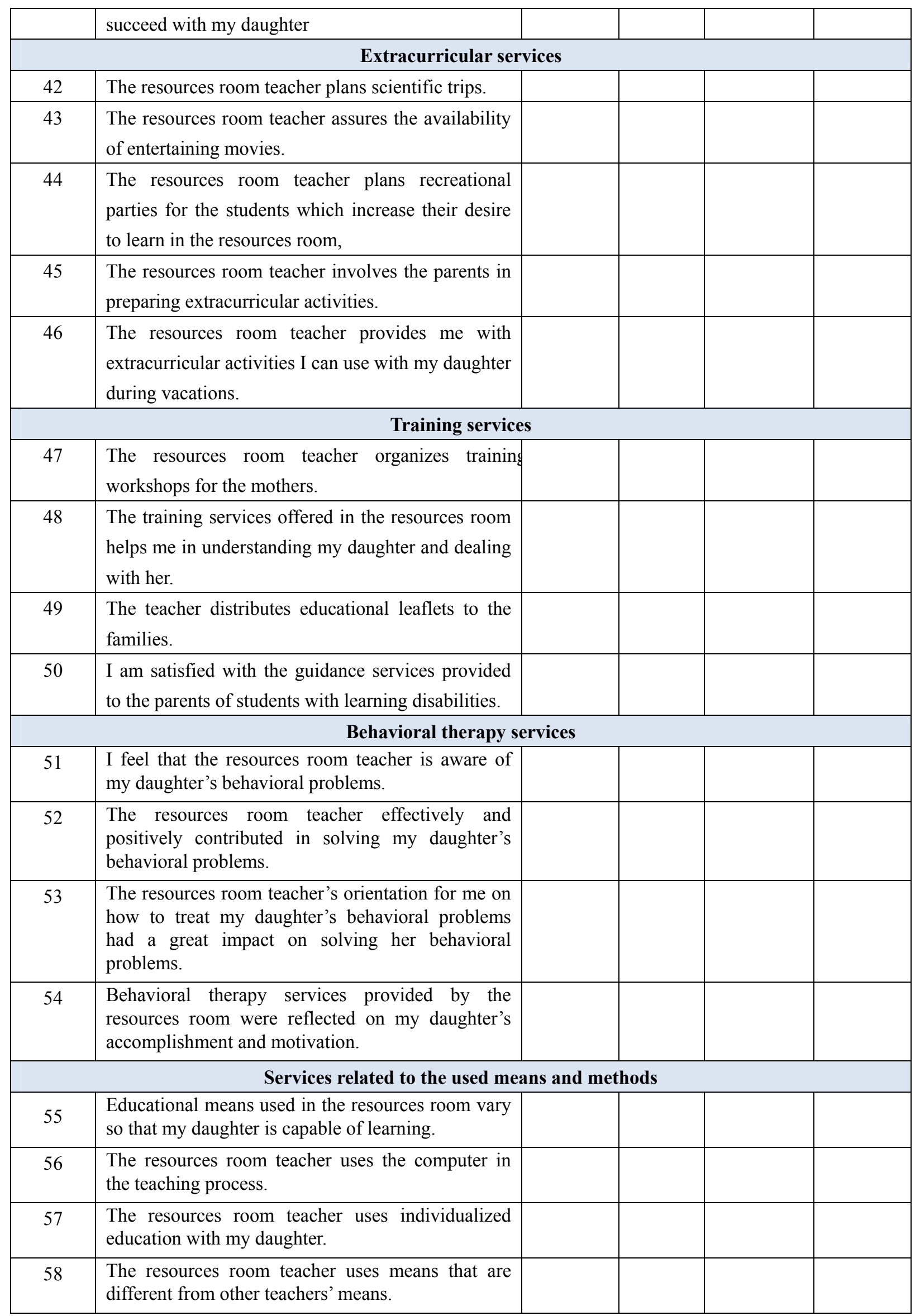




\section{Copyrights}

Copyright for this article is retained by the author(s), with first publication rights granted to the journal.

This is an open-access article distributed under the terms and conditions of the Creative Commons Attribution license (http://creativecommons.org/licenses/by/3.0/). 